Rok XIV (2019) | 2 (28) | s. 43-55

https://doi.org/10.12797/LV.14.2019.28.03

Krzysztof Tomasz Witczak @

Uniwersytet Łódzki, tódź

krzysztof.witczak@uni.lodz.pl

\title{
HIPOTEZA WITOLDA MAŃCZAKA O UGROFIŃSKIM SUBSTRACIE W JĘZYKACH BAŁTYCKICH
}

Słowa klucze: języki bałtyckie, kontakty językowe, substrat, wpływ ugrofiński

Keywords: Baltic languages, language contacts, substrate, Finno-Ugric influence

\section{Wprowadzenie}

W niniejszej publikacji chciałbym przedstawić najnowszy stan dyskusji nad problemem uralskiego substratu w językach bałtyckich ze szczególnym omówieniem hipotezy Witolda Mańczaka o jego ugrofińskim (zwłaszcza bałtofińskim) charakterze. Przegląd opinii zarówno dawnych badaczy, jak i współczesnego dwugłosu (W. Mańczak vs Jan Henrik Holst) zamierzam zaprezentować w sposób obiektywny i informatywny. Artykuł zakończę krótką opinią o prezentowanym zagadnieniu.

\section{Zagadnienie substratu w językach bałtyckich. Krótki przegląd wcześniejszych opinii}

Języki bałtyckie, tworzące osobną grupę w obrębie rodziny indoeuropejskiej, są rozprzestrzenione na terenach nadbałtyckich. Wyróżniamy dwa zasadnicze ugrupowania języków bałtyckich:

1) języki wschodniobałtyckie, reprezentowane przez dwa języki literackie: litewski i łotewski; 
2) języki zachodniobałtyckie, obecnie wymarłe, w których skład wchodził język staropruski (w jego odmianie pomezańskiej i sambijskiej) oraz język jaćwieski. W przeszłości istniały też zapewne inne ugrupowania języków bałtyckich, których użytkownicy posługiwali się przypuszczalnie odmienną mową, np. Galindowie, poświadczeni szczątkowo pomiędzy Prusami i Jaćwingami, w okolicy Jeziora Golędzkiego, a także na wschodzie Europy (nad rzeką Oką i Moskwą) pod ruską nazwą Goliadzi (Toporov 1980: 247-252)1.

W dobie historycznej ludy bałtyckie sąsiadowały (i zasadniczo do tej pory sąsiadują) z ludami germańskimi i słowiańskimi, a także z ludnością uralską, wchodzącą w skład ugrupowania bałtofińskiego (chodzi tu o Estończyków, Finów, Karelów, Liwów, Wepsów itd.). Najdawniejsi badacze sygnalizowali kontakty językowe pomiędzy tymi ludami i dopatrywali się wzajemnych wpływów uralsko-indoeuropejskich. Uważali nawet, że języki bałtyckie pojawiły się na skutek długotrwałego mieszania się elementów słowiańskich, germańskich i fińskich (Thunmann 1772; Watson 1822). Rasmus Ch. Rask (1818: 153) jako pierwszy uczony zasugerował wzajemne oddziaływania pomiędzy ludnością bałtycką i ugrofińską (uralską), przy czym wpływ języków bałtyckich na bałtofińskie miał być intensywniejszy od oddziaływania odwrotnego. August Ahlqvist (1875) zbadał zapożyczenia kulturalne $\mathrm{w}$ językach zachodniofińskich przejęte $\mathrm{z}$ zachodu, $\mathrm{z}$ południa i wschodu, $\mathrm{w}$ tym także zapożyczenia bałtyckie, słowiańskie i indoirańskie. Nikolai Anderson (1879) był przekonany o wyższości kultury ludów indoeuropejskich, toteż wszelkie zbieżności bałtycko-(ugro)fińskie rozpatrywał jako wynik wpływu Bałtów na szeroko pojęte ludy fińskie. Inni badacze proponowali rozwiązania kompromisowe, przyjmując, że pożyczki językowe mogły wędrować w obu kierunkach (Donner 1884; Veske 1890). Niektórzy uważali, że zapożyczenia bałtyckie są zdecydowanie liczniejsze, ale jednocześnie brali pod uwagę ewentualność, że niektóre zbieżności mogą być świadectwem pradawnego pokrewieństwa uralsko-indoeuropejskiego (tak m.in. Diefenbach 1880: 237). Rozważano też możliwość zapożyczenia z nieznanego (trzeciego) źródła (tak niekiedy Anderson 1879). Vilhelm Thomsen (1890: 68-71) dowodził natomiast, że zapożyczenia ugrofińskie w językach bałtyckich są późne i ograniczają się zasadniczo do języka łotewskiego i żmudzkiego. Obecność (ugro)finizmów w innych językach bałtyckich (m.in. w litewskim i staropruskim) objaśniał ich wtórnym przenikaniem za pośrednictwem łotewskiego i żmudzkiego. Zwykle jednak stał na stanowisku, że wyrazy poświadczone we wszystkich językach bałtyckich (wliczając $\mathrm{w}$ to litewski i staropruski) są rodzime, a ich odpowiedniki bałtofińskie to praw-

1 Jan Henrik Holst (2009: 66-67, 2015: 155-156) wyróżnia trzecie ugrupowanie bałtyckie, mianowicie południowe (niem. Südbaltisch, ang. South Baltic), a za głównego reprezentanta wymarłych języków południowobałtyckich uznaje język tracki, używany w dobie starożytnej na Bałkanach. Autor odwołuje się do badań Ivana Duridanova (1985), poświęconych licznym zbieżnościom leksykalnym języka trackiego i języków bałtyckich. 
dopodobne zapożyczenia przejęte ze źródła bałtyckiego. Z kolei Jalo Kalima (1936) prezentował odmienny pogląd, zgodnie z którym kierunek zapożyczenia musi być uznany za niepewny, jeśli wyrazy bałtyckie nie posiadają odpowiedników w innych językach indoeuropejskich.

Gwałtowny rozwój badań indoeuropeistycznych sprzyjał raczej przekonaniu o silnych wpływach indoirańskich, bałtyckich, germańskich i słowiańskich na języki fińskie niż opozycyjnej hipotezie o alternatywnym kierunku oddziaływania. Podejmowane próby poszukiwania źródła zapożyczenia leksykalnego w językach uralskich (Ariste 1955; Loja 1958) były ostro krytykowane (Kiparsky 1959; Junttila 2015), podobnie jak uzupełniające sugestie, że wpływy uralskie są widoczne zarówno w językach bałtyckich, jak i słowiańskich (Polák 1964; Bednarczuk 1976). Dość dobrze zbadane zostały obustronne konwergencje łotewsko-estońskie (Zeps 1962), jednak w literaturze przedmiotu do tej pory przeważa tradycyjne przekonanie, że języki bałtyckie silnie oddziaływały na języki bałtycko-fińskie (Kallio 2008), w nieco mniejszym stopniu na wołżańsko-fińskie, tj. języki czeremiski (maryjski) i mordwiński (Mägiste 1959; Pareren 2008; Grünthal 2012).

Wpływ uralski (a ściślej bałtycko-fiński lub wołżańsko-fiński) na języki bałtyckie jest zwykle pomijany lub redukowany do minimum, chociaż liczne bałtyzmy leksykalne w językach bałtofińskich, a także w językach wołżańsko-fińskich dowodzą intensywnych kontaktów pomiędzy Bałtami i Finami (Ugrofinami) w okresie przedhistorycznym. Co więcej, historyczna i współczesna toponimia i hydronimia ziem bałtosłowiańskich o ugrofińskim charakterze dowodzi, że ludność indoeuropejska (w danym regionie: bałtycka i słowiańska) nawarstwiła się na jakiś ugrofiński substrat językowy należący do rodziny uralskiej.

\section{Fakty przemawiające za hipotezą ugrofińskiego substratu}

W. Mańczak (1990: 34-35, 1992: 151, 2008: 149-152) wylicza następujące przesłanki świadczące o występowaniu jakiegoś substratu fińskiego (uralskiego) w językach bałtyckich, za każdym razem odwołując się do istniejącej już wcześniej literatury przedmiotu:

3.1. Zanik rodzaju nijakiego obserwowany $w$ języku litewskim i łotewskim pojawił się, zdaniem Antoine’a Meilleta (1925: 100-101), pod wpływem języków bałtycko-fińskich, gdyż kategoria rodzaju nie występuje w językach ugrofińskich.

3.2. W języku (staro)litewskim występują sekundarne przypadki lokalne (tj. illativus, allativus, adessivus, inessivus), utworzone za pomocą postpozycji według wzoru ugrofińskiego (ibid.: 101). 
3.3. Konstrukcje litewskie typu nešęs velnias akmenị (wyrażające modalność imperceptywną) 'diabeł, jak mówią, przyniósł kamień' (dosłownie 'przyniósłszy diabeł kamień'), a także ich łotewskie odpowiedniki, pojawiły się, zdaniem Vittore Pisaniego (1959: 217), pod wpływem substratu.

3.4. Litewskie liczebniki 11-19 zakończone na -lika (np. lit. vienúolika 'jedenaście’, dvýlika 'dwanaście' itd.) mają genezę substratową (ibid.).

3.5. Partykuła litewskiego imperatywu na $-k i$ lub $-k$ (np. stlit. duóki 'daj') powiela, zdaniem niektórych badaczy (Toporov, Trubačev 1962: 249-250), podobną partykułę funkcjonującą w języku fińskim.

3.6. Alternacja spółgłosek dźwięcznych i bezdźwięcznych typu lit. blẽ kai/plẽ kai 'flaki, jelita zwierzęce; potrawa z flaków' (Kiparsky 1968: 76-90 wylicza około 300 par dubletów w języku łotewskim i 50 par w języku litewskim) może być spowodowana wpływem substratu ugrofińskiego, jako że języki ugrofińskie posiadały niegdyś wyłącznie spółgłoski bezdźwięczne.

3.7. Istnieją zapożyczenia ugrofińskie we wszystkich językach bałtyckich, np. nazwa bursztynu: stprus. gentars, lit. giñtaras, łot. dzĩtars m. 'bursztyn, jantar' (Bednarczuk 1976: 47-48), por. czer. jamdar 'szkło; jasny, przezroczysty', węg. gyanta 'żywica; kalafonia', gyantar 'bursztyn'.

3.8. Użycie dopełniacza zamiast przymiotnika w językach wschodniobałtyckich (np. lit. lietuviu kalbà ' język litewski', dosłownie 'język Litwinów', łot. latviešs valoda 'język łotewski', dosłownie 'język Łotyszy') zostało wywołane wpływem fińskim, por. fi. suomen kieli 'język fiński', est. eesti keel 'język estoński' (Bednarczuk 1968: 482).

3.9. Na obszarze Łotwy znajdują się liczne hydronimy pochodzenia ugrofińskiego, podczas gdy na Litwie wyróżniamy hydronim Niemen (lit. Nemunas) oraz około 30 innych nazw wodnych mających ugrofińską genezę (Zinkevičius 1984: 155).

3.10. Brak rozróżnienia liczby w trzeciej osobie litewskich, łotewskich i staropruskich form czasownikowych był, zdaniem niektórych badaczy (np. Thomason, Kaufman 1988: 243), wywołany wpływem bałtofińskim.

$\mathrm{Na}$ bazie powyższych argumentów, wcześniej już wskazanych przez innych językoznawców diachronistów, Mańczak (1990: 34, 1992: 151) doszedł do przekonania, że języki bałtyckie (tj. litewski, łotewski i staropruski) rozwinęły się na substracie ugrofińskim, zwłaszcza fińskim, a ściślej mówiąc: bałtofińskim. Jednocześnie zwrócił uwagę, że „ślady substratu fińskiego są najliczniejsze w łotewskim, mniej liczne w litewskim, a najmniej liczne w staropruskim" (Mańczak 1992: 151). Obserwowana 
intensywność wpływów bałtofińskich w poszczególnych językach bałtyckich pozwoliła mu wnioskować, że „indoeuropeizacja obszaru bałtyckiego dokonywała się z południa na północ” (ibid.: 151).

\section{Krytyka poglądów Witolda Mańczaka na etnogenezę ludów bałtyckich}

Z krytyką tezy W. Mańczaka wystąpił w ostatnim czasie J.H. Holst (2015: 151-173), który przytoczył obszerną kontrargumentację, zbijającą krok po kroku 10 argumentów podanych przez polskiego badacza. Holst nie zaprzecza, że istniały dawne kontakty pomiędzy językami bałtyckimi i (bałto)fińskimi, ale uważa, że dochodziło do nich już w epoce samodzielnego rozwoju poszczególnych języków bałtyckich, głównie wschodniobałtyckich. Jego zdaniem nie ma żadnego dowodu na to, że języki bałtyckie wchłonęły dawniej jakiś nieznany substrat ugrofiński. Ponadto sądzi, że polski językoznawca bez żadnej istotnej przyczyny przenosi zjawiska obserwowane $\mathrm{w}$ dobie nowożytnej do epoki prabałtyckiej.

Przyjrzyjmy się bliżej polemicznym wypowiedziom J.H. Holsta odnoszącym się do zwięzłej argumentacji W. Mańczaka. Podaję je w takiej samej kolejności, w jakiej prezentowali je obaj badacze.

4.1. Rodzaj nijaki. W językach wschodniobałtyckich, tj. w litewskim i łotewskim, nastąpił zanik rodzaju nijakiego, co już Meillet (1925) powiązał z faktem, że w językach ugrofińskich nie spotykamy kategorii rodzaju. Holst podejmuje polemikę z tym poglądem, słusznie podkreślając, iż język staropruski zachował rodzaj nijaki, por. stprus. assaran n. 'jezioro' wobec lit. ẽžeras m. 'jezioro', łot. ezers m. 'ts.' (Derksen 2015: 158) ${ }^{2}$. Rodzaj nijaki jest doskonale poświadczony na gruncie słowiańskim (por. pol. jezioro, cz. jezero, ros. ózepo n. 'jezioro') ${ }^{3}$. Zanik rodzaju nijakiego, jak stwierdza Holst, nastąpił zatem wyłącznie na gruncie wschodniobałtyckim. Holst odrzuca wpływ substratu ugrofińskiego na bazie trzech kontrargumentów. Po pierwsze, zanik rodzaju nijakiego nie jest zjawiskiem ogólnobałtyckim, co skłania do mniemania, iż mamy do czynienia $z$ innowacją wschodniobałtycką. Po drugie, gdyby przyjąć wpływ ugrofiński, to spodziewalibyśmy się eliminacji kategorii rodzaju w całości, a nie tylko usunięcia rodzaju nijakiego. Po trzecie, liczne języki indoeuropejskie poświadczają zanik rodzaju nijakiego, np. łacina posiadała trzy rodzaje, a pochodne języki romańskie (np. język francuski i włoski) mają tylko dwa (rodzaj męski i żeński). Podobna zmiana zaszła także w językach celtyckich, irańskich i indyjskich. Nawet niektóre dialekty słowiańskie zgubiły rodzaj nijaki,

\footnotetext{
2 Dodać trzeba, że do tego gniazda wyrazowego należy także apelatyw jaćwieski ziro 'jezioro', reprezentujący bez wątpienia nomen neutrum zakończone na -o (jak w językach słowiańskich).

3 Por. także wed. akṣáram n. 'woda' (pierwotnie 'stojąca woda, jezioro').
} 
np. słoweński dialekt Sele Fara (Corbett 1991: 216, 317). Holst dostrzega odmienną przyczynę zanikania rodzaju nijakiego $\mathrm{w}$ różnych ugrupowaniach języków indoeuropejskich. Jego zdaniem odmiana rzeczowników rodzaju męskiego i nijakiego w podstawowych typach deklinacyjnych (zwłaszcza w najbardziej popularnych formacjach nominalnych mających osnowę na -o-) w niewielkim stopniu różniła się od siebie (rozbieżne formy pojawiają się tylko w mianowniku liczby pojedynczej i mnogiej oraz w bierniku liczby mnogiej, pozostałe przypadki są identyczne). Konkluduje zatem, że z powodu licznych paralelnych zjawisk w innych językach indoeuropejskich „the development of gender in East Baltic does not require an explanation with a substratum at all" (Holst 2015: 159).

4.2. Przypadki lokalne. Holst rozprawia się z tym argumentem krótko i zdecydowanie. Jego zdaniem jedynie język litewski rozwinął nowe przypadki lokalne za pomocą postpozycji. Holst wskazuje, że Meillet (1925: 1001) uwydatnił paralelę ugrofińską („la concordance avec le type finnois est frappante” [zgodność z fińskim pierwowzorem jest uderzająca]), ale bynajmniej nie dowodził, że wprowadzenie przypadków lokalnych w języku litewskim ma genezę substratową. Nowe przypadki litewskie są relatywnie młode i na pewno nie pochodzą z epoki prabałtyckiej. Ponadto zjawisko wprowadzania nowych przypadków zostało także zaobserwowane w historii języków indoirańskich (np. osetyńskiego) i języków tocharskich.

4.3. Ewidencjalność. Niektóre języki bałtyckie i bałtofińskie mają możliwość wyrażenia czegoś, co specjaliści od typologii językowej określają jako ewidencjalność lub imperceptywność. Termin ten odnosi się do przypadku, kiedy osoba wypowiadająca się zna coś ze słyszenia i pragnie to w odpowiedni sposób uwydatnić (poprzez odpowiedni modus relativus). Problemem tym zajmowali się inni badacze (Haarmann 1970; Aikhenvald 2004). Holst zgadza się, że zbieżność fińsko-bałtycka jest wyjątkowa i zasługuje na szczególną uwagę, chociaż ewidencjalność jako taka jest dość pospolitym zjawiskiem w żywych językach Eurazji. Podkreśla jednak, że ewidencjalność znają jedynie dwa języki bałtofińskie - estoński i liwoński. Ponadto stwierdza, że nie ma pewności, w którym kierunku przebiegał wpływ. Holst zakłada, że imperceptywność jest zjawiskiem relatywnie młodym w estońskim i liwońskim, skoro inne języki bałtofińskie i zapewne ugrofińskie go nie znają. Chociaż w języku staropruskim nie widać śladów modalności imperceptywnej (Endzelins 1923: 757), Holst (2015: 160-162) uznaje ewidencjalność za dawną cechę ogólnobałtycką, ale jednocześnie wyklucza, by domniemany substrat ugrofiński miał jakikolwiek wpływ na jej uformowanie w językach bałtyckich.

4.4. Liczebniki od 11 do 19. Język litewski tworzy liczebniki od 11 do 19 za pomocą morfemu -lika, np. vienúolika 'jedenaście', dvýlika 'dwanaście'. V. Pisani (1959: 217) sugeruje, że te liczebniki mogły powstać pod wpływem nieznanego substratu. 
Dopiero Mańczak (2008: 150) precyzuje, że chodzi o substrat ugrofiński. Języki bałtofińskie budują te liczebniki w podobny sposób, ale wykorzystują inaczej brzmiący morfem (fi. -toista, est. -teist), np. fi. nejlätoista 'czternaście'. Holst odrzuca zbieżność ze względu na to, że liczebniki bałtyckie do złudzenia przypominają germańskie liczebniki zakończone morfemem -lif, np. goc. ainlif 'jedenaście' (= ang. eleven), twalif 'dwanaście' (= ang. twelve). Holst (2015: 162) sprowadza litewski morfem -lika do rdzenia ie. ${ }^{*} l e i k^{u}$ - 'pozostawiać. Podkreśla także, że język łotewski inaczej buduje liczebniki od 11 do 19. W języku staropruskim stosowne liczebniki się nie zachowały, toteż brakuje dowodu, że liczebniki na -lika występowały w epoce prabałtyckiej.

4.5. Rozkaźnik z cechą -k(i). Język litewski buduje imperativus za pomocą partykuły $-k(i)$, por. stlit. duóki 'daj', lit. dìrbk 'rób, pracuj' (pierwotna partykuła *-ki-została utrwalona w formie 2 os. pl. dirbkite). Także w językach bałtofińskich pojawia się przyrostek $-k$ tworzący tryb rozkazujący. Ponieważ inne języki indoeuropejskie nie znają takiej cechy rozkaźnika, niektórzy badacze (Toporov, Trubačev 1962: 249-250; Mańczak 2008: 150) doszli do przekonania, że ludy bałtyckie zapożyczyły tę partykułę od ludności ugrofińskiej. Holst (2015: 163) jest zdania, że postulowana zbieżność jest przypadkowa, a imperativus na - $k$ - jest relatywnie późną innowacją języka litewskiego.

4.6. Wahanie spółgłosek dźwięcznych i bezdźwięcznych w nagłosie wyrazów. W tym przypadku Mańczak odsyła do artykułu Valentina Kiparsky'ego (1968), w którym przytoczono około 300 przykładów łotewskich i około 50 litewskich, a także dano garść analogicznych przykładów z języka liwskiego, np. łot. bakalpaka 'paczka' obok liw. bak/pak 'ts.'; łot. zuoste/suoste 'sos' obok liw. sùoś/zùost 'ts.'. Przykłady te jasno pokazują, że warianty ze spółgłoską dźwięczną i bezdźwięczną szerzą się łatwo w kontakcie językowym ludności ugrofińskiej i bałtyckiej. Przyczyna tego zjawiska jest dość prosta i Kiparsky (ibid.: 92-97) szczegółowo ją opisuje na przykładzie pogranicza łotewsko-liwskiego. Języki ugrofińskie nie miały dawniej spółgłosek dźwięcznych, toteż zapożyczając wyrazy bałtyckie, wprowadzały spółgłoski bezdźwięczne w miejscu dźwięcznych. Te wyrazy powracały w formie ubezdźwięcznionej do języków bałtyckich. W późniejszym czasie, pod wpływem liwskim, gdzie występuje spontaniczne udźwięcznienie wygłosu (np. liw. nāk [na:g] 'przychodzi') i pod wpływem sandhi także nagłosu, pojawiły się w języku łotewskim formy hiperpoprawne z nagłosem dźwięcznym, por. pol. paka wobec łot. bakalpaka 'paczka' liw. bak/pak 'ts.'. Holst jednak uważa, że Mańczak, cytując artykuł Kiparsky’ego, nazbyt uprościł problem. Kiparsky bowiem uznał język liwski za źródło szerzących się wariacji form z nagłosem dźwięcznym i bezdźwięcznym w języku łotewskim i pośrednio też w litewskim. Kiparsky nigdzie nie twierdzil, że geneza tej wariacji ma charakter substratowy i sięga epoki prabałtyckiej. Holst (2015: 164) uważa, że Mańczak popełnił błąd natury chronologicznej, uznając wariację spółgłosek dźwięcznych 
i bezdźwięcznych za zjawisko prajęzykowe (ogólnobałtyckie), i jednocześnie zignorował rolę języka liwskiego w szerzeniu się tej nietypowej na gruncie indoeuropejskim alternacji. Zdaniem Holsta (ibid.: 164) wahanie typu $b$-/p- jest relatywnie późnym zjawiskiem spowodowanym przez kontakt językowy, a nie zjawiskiem wywołanym przez wpływ ugrofińskiego substratu.

4.7. Użycie dopełniacza zamiast przymiotnika. Ludy indoeuropejskie używają z reguły przymiotnika dla określenia jakiegoś języka, np. pol. język polski, ros. pyccкuŭ язык, ang. the English language, fr. la langue française, hiszp. la lengua española, niem. die deutsche Sprache, wł. la lingua italiana. Wśród języków indoeuropejskich inaczej postępują tylko języki bałtyckie, które zamiast przymiotnika używają dopełniacza, np. lit. lietuvių kalbà 'język litewski' (dosłownie 'język Litwinów'), łot. latviešu valoda 'język łotewski’ (dosłownie ‘język Łotyszy’). Mańczak przypuszcza, że powyższe zjawisko zostało wywołane wpływem fińskim, por. fi. suomen kieli 'język fiński', est. eesti keel 'język estoński'. Holst nie neguje wprawdzie tego podobieństwa, ale nie uznaje pełnego paralelizmu form. Oznajmia też, że „the direction of the influence, if it exists, is not clear" (ibid.: 164).

4.8. Zapożyczenia. Mańczak przytoczył bałtycki wyraz oznaczający 'bursztyn, jantar' jako przykład pradawnego zapożyczenia (ugro)fińskiego, powołując się na opinię Leszka Bednarczuka (1976: 47-48). Hamburski polemista słusznie podkreśla, że „a single word can probably not serve as good evidence for a substratum” (Holst 2015: 165) ${ }^{4}$. Zauważa także, że zbieżność pomiędzy wyrazami ugrofińskimi (por. węg. gyanta 'żywica; kalafonia', gyantar 'bursztyn', czer. jamdar 'szkło; jasny, przezroczysty') oraz bałtyckimi (por. stprus. gentars m. 'bursztyn', lit. giñtaras m. 'ts.', żm. gintars, łot. dzĩtars, kur. dziñtars 'ts.'; Derksen 2015: 2) opiera się na niepewnej etymologii oraz na $\mathrm{z}$ góry założonym kierunku zapożyczenia. Podkreśla ponadto fakt, iż materiał leksykalny nie daje pewności, że źródłem tych słów były języki bałtofińskie, które dokumentują zresztą odmienne nazwy bursztynu (por. fi. meripihka 'bursztyn, jantar', dosłownie 'morska żywica', est. merevaik 'ts.', także pihkaki$v i$ 'bursztyn', dosł. 'żywiczny kamień').

4.9. Hydronimia. Holst przywołuje ustalenia bałtologów w kwestii występowania hydronimów fińskiego pochodzenia na terenie Litwy (około 30 nazw rzecznych) i na obszarze Łotwy (około 30o) (Zinkevičius 1984: 155), dodając przy tym, że Mańczak wykorzystał ten argument, by wzmocnić hipotezę o ugrofińskim substracie w językach bałtyckich. Holst polemizuje z Mańczakiem w następujący sposób: na

4 W tym miejscu Holst wydaje się nie pamiętać, że tytuł artykułu Bednarczuka (1976) brzmiał Zapożyczenia ugrofińskie $w$ językach bałtosłowiańskich i obejmował 65 wybranych jednostek leksykalnych. 
terenie Niemiec są liczne nazwy miejscowe słowiańskiego pochodzenia, ale to nie dowodzi istnienia słowiańskiego substratu w języku niemieckim (lub pragermańskim). Hydronimy świadczą tylko o tym, że ludy bałtyckie ekspandowały z południa na północ, stopniowo spychając ludy fińskie, zwłaszcza Liwów, na dalsze terytoria. Analogiczna sytuacja jest dostrzegana w Niemczech. Nazewnictwo słowiańskie pojawia się we wschodniej części Niemiec, gdzie osadnictwo Słowian jest potwierdzone przez źródła historyczne. Holst podkreśla ponadto, że Zigmas Zinkevičius błędnie przypisał niektórym hydronimom litewskim lub łotewskim pochodzenie fińskie.

4.10. Brak rozróżnienia liczby trzeciej osoby. W językach bałtyckich nie ma odróżnienia liczby w formach czasownikowych trzeciej osoby, por. łot. bèrns èd 'chłopiec je', bèrni èd 'chłopcy jedzą'. Holst wyklucza, żeby było to spowodowane wpływem fińskim, nawet jeśli w języku estońskim czasownik on oznacza zarówno 'jest', jak i 'są' (por. lit. yrà 'jest, są', łot. ir 'ts.'). Uważa, że zanik rozróżnienia jest czysto bałtycką innowacją, u której podstaw leżą odziedziczone nazwy zbiorowe (kolektywa), które łączyły się z czasownikiem w liczbie pojedynczej, por. pol. leci liście z drzewa

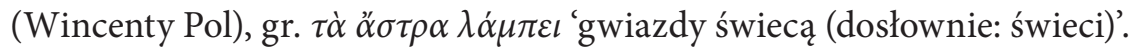

\section{Komentarz do polemiki Jana Henrika Holsta z Witoldem Mańczakiem}

Głównym zarzutem Holsta w odniesieniu do hipotezy substratu ugrofińskiego jest brak precyzyjnie zdefiniowanej chronologii nawarstwienia się ludności prabałtyckiej na ów przypuszczalny substrat. Należy jednak zauważyć, że Mańczak nigdy nie tworzył wizji interdyscyplinarnej, zawsze operował materiałem językowym i zawsze tylko do niego się odwoływał, chociaż w dyskusji przytaczał też opinie archeologów, historyków, etnografów oraz przedstawicieli innych nauk, a niekiedy z nimi ostro polemizował. Według Bednarczuka (1992: 116) plemiona prabałtyckie usamodzielniły się około 1500 r. p.n.e., a ich kontakty z ludami prafinowołżańskimi i prafinolapońskimi trwały do początków naszej ery. Po tym okresie ożywiony kontakt językowy pozostał jedynie pomiędzy językami wschodniobałtyckimi i prafinobałtyckimi. Przyjmując hipotezę o egzystencji substratu ugrofińskiego w językach bałtyckich, należałoby oczekiwać, że wpływy i zapożyczenia substratowe należy odnosić do II i I tysiąclecia p.n.e. Nie jest jednak wykluczone, że pierwsze kontakty ugrofińsko-bałtyckie miały miejsce już w III tysiącleciu p.n.e. W tym bowiem okresie na południowo-zachodni obszar kultury ceramiki dołkowo-grzebykowej (ok. 4200-2000 p.n.e.), powszechnie kojarzony z ludami uralskimi, nawarstwiła się kultura ceramiki sznurowej (2900-2350 p.n.e.), pochodząca z kręgu neolitycznych kultur naddunajskich, której granice rozciągały się od Renu na zachodzie aż po Wołgę na wschodzie. Możemy zakładać, że w wyniku tego zdarzenia na dawnym podłożu ugrofińskim ukształtowała się wspólnota lub liga bałtosłowiańska. 
Czy jakiś substrat uralski istniał w Europie Środkowej i Wschodniej? Przywołajmy niezależną wypowiedź Tadeusza Milewskiego:

Elementy uralskie są najstarszą dostępną nam warstwą lingwistyczną Europy wschodniej i środkowej. Nazwy rzek pochodzenia uralskiego, wykazujące pokrewieństwo z wyrazami fińskimi, sięgają aż po Odrę, jak to wykazują materiały zebrane ostatnio przez T. Lehra-Spławińskiego ${ }^{5}$ [...]. Oczywiście ci pierwotni mieszkańcy dorzecza Wisły i obszarów sąsiednich nie mówili żadnym z historycznie znanych nam języków ugrofińskich, które w owym czasie (trzecie i drugie tysiąclecie przed Chr.) występowały nad Wołgą i na zboczach Uralu. W Europie środkowej natomiast panowała jakaś inna, nieznana nam bliżej gałąź rodziny uralskiej, której ludność różniła się od Ugrofinów typem antropologicznym. Językowe elementy uralskie w Europie środkowej należy łączyć z silną tam i starą warstwą rasy laponoidalnej, której typowi przedstawiciele charakteryzują się wzrostem niskim, krępą budową ciała, płowo-żółtą skórą, okrągłą głową oraz szeroką i płaską twarzą. Do tej rasy antropologicznej należą dziś z ludów uralskich tylko Samojedzi i Lapończycy (Milewski 1948: 201).

W świetle tej wypowiedzi mamy pełne prawo oczekiwać, że ludy prabałtyckie i prasłowiańskie musiały wchłonąć pewną liczbę uralskich zapożyczeń substratowych. Można także przypuszczać, że ów substrat wpłynął znacząco (choć w różnym stopniu) na strukturę języków bałtyckich.

\section{Konkluzje}

W niniejszej pracy przedstawiono argumenty świadczące o wpływach domniemanego „substratu uralskiego” na języki bałtyckie (Mańczak 1990, 1992, 2008) ${ }^{6}$. Omówiono też polemikę, jaką z tezami W. Mańczaka podjął w ostatnim czasie J.H. Holst (2015). Autor ograniczył się do przedstawienia aktualnego stanu badań na kanwie zaistniałego dwugłosu?

5 Por. Lehr-Spławiński 1946: 81-86.

6 Artykuł jest częścią projektu badawczego pt. „Prehistoryczne kontakty indoeuropejsko-uralskie” finansowanego w ramach funduszu rozwoju naukowego Wydziału Filologicznego Uniwersytetu Łódzkiego.

7 W innej rozprawce (Witczak, w druku) autor artykułu wyraża opinię o dostrzeżonych przez Witolda Mańczaka śladach substratu ugrofińskiego w językach bałtyckich i szczegółowo omawia słabości argumentacji strony przeciwnej. 


\section{Skróty}

ang. - angielski; cz. - czeski; czer. - czeremiski (maryjski); est. - estoński; fi. - fiński; fr. francuski; goc. - gocki; gr. - grecki; hiszp. - hiszpański; ie. - indoeuropejski; kur. - kuroński; lit. - litewski; liw. - liwski; łot. - łotewski; niem. - niemiecki; pol. - polski; ros. - rosyjski; stlit. - starolitewski; stprus. - staropruski; wed. - wedyjski; węg. - węgierski; wł. - włoski; żm. - żmudzki

\section{Literatura}

AHLQvist A., 1875, Die Kulturwörter der westfinnischen Sprachen. Ein Beitrag zu der älteren Kulturgeschichte der Finnen, Helsingfors.

Aikhenvald A.V., 2004, Evidentiality, Oxford.

Anderson N., 1879, Studien zur Vergleichung der ugrofinnischen und indogermanischen Sprachen, Dorpat.

Ariste P.A., 1955, Primečaniâ, [w:] L. Hakulinen, Razvitie i struktura finskogo âzyka, t. II: Leksikologiâ i sintaksis, Moskva, s. 278-286.

BEDNARCZUK L., 1968, Ze stosunków językowych bałtosłowiańsko-ugrofińskich, „Sprawozdania z Posiedzeń Komisji Naukowych PAN. Oddział w Krakowie” XII, s. 481-483.

BednARCZuk L., 1976, Zapożyczenia ugrofińskie w jezykach bałtosłowiańskich, „Acta Baltico-Slavica" 9, s. 39-64.

BednARCzUK L., 1992, Konwergencje między językami bałtosłowiańskimi a ugrofińskimi $w$ aspekcie strukturalnym i arealnym, [w:] W. Smoczyński, A. Holvoet (red.), Colloquium Pruthenicum Primum. Papers from the First International Conference on Old Prussian, held in Warsaw, September $30^{\text {th }}$ - October $1^{\text {st }}$, 1991, Warszawa, s. 99-119.

Corbett G., 1991, Gender, Cambridge.

DERKSEN R., 2015, Etymological Dictionary of the Baltic Inherited Lexicon, Leiden - Boston.

Diefenbach L., 1880, Völkerkunde Osteuropas, insbesondere der Haemoshalbinsel und der unteren Donaugebiete, t. II, Darmstadt.

Donner O., 1884, Über den Einfluss des Litauischen auf die finnischen Sprachen, „Techmers Internationale Zeitschrift für allgemeine Sprachwissenschaft” I, s. 257-271.

Duridanov I., 1985, Die Sprache der Thraker, Neuried.

ENDZELINS J., 1923, Lettische Grammatik, Heidelberg.

Grünthal R., 2012, Baltic Loanwords in Mordvin, [w:] idem, P. Kallio (red.), A Linguistic Map of Prehistoric Northern Europe, Helsinki, s. 297-343.

HAARMANn H., 1970, Die indirekte Erlebnisform als grammatische Kategorie. Eine eurasische Isoglosse, Wiesbaden.

Holst J.H., 2009, Armenische Studien, Wiesbaden.

Holst J.H., 2015, On the Theory of a Uralic Substratum in Baltic, [w:] S. Junttila (red.), Contacts between the Baltic and Finnic Languages, Helsinki, s. 151-173.

Junttila S., 2015, Proto-Finnic Loanwords in the Baltic Languages?, [w:] idem (red.), Contacts between the Baltic and Finnic Languages, Helsinki, s. 12-37.

Kalima J., 1936, Itämerensuomalaisten kielten balttilaiset lainasanat, Helsinki. 
Kallio P., 2008, On the „Early Baltic” Loanwords in Common Finnic, [w:] Evidence and Counter-Evidence. Essays in Honour of Frederik Kortlandt, t. 1, Amsterdam - New York, s. 261-296, [on-line:] https://doi.org/10.1163/9789401206358_020.

KipARSKy V., 1959, Kielitieteen peruskysymyksiä, „Virittää” LXIII, nr 3, s. 421-425.

Kiparsky V., 1968, Slavische und baltische b/p-Fälle, „Scando-Slavica” XIV, s. 73-97.

LeHr-SpŁAWIŃski T., 1946, O pochodzeniu i praojczyźnie Słowian, Poznań.

LoJA J., 1958, Valodniecības pamatjautājumi, Riga.

MańczaK W., 1990, La communauté balto-slave a-t-elle existé?, „Baltistica” 26, nr 1, s. 29-38, [on-line:] http://dx.doi.org/10.15388/baltistica.26.1.179.

MaŃCZAK W., 1992, Krytyka etnogenetycznej koncepcji Ludovíta Nováka, [w:] „Z Polskich Studiów Slawistycznych", seria 8, Warszawa, s. 147-152.

MaŃCZAK W., 2008, Linguistique générale et linguistique indo-européenne, Kraków.

MäGISTE J., 1959, Gibt es im Tscheremissischen baltische Lehnwörter?, „Ural-Altaische Jahrbücher” XXXI, s. 169-176.

Meillet A., 1925, La méthode comparative en linguistique historique, Oslo.

Milewski T., 1948, Zarys językoznawstwa ogólnego, cz. II: Rozmieszczenie języków, z. 1: Tekst, Lublin - Kraków.

PAREREN R. VAN, 2008, Die direkten baltischen Lehnwörter im Mordwinischen, „Finnisch-Ugrische Mitteilungen” XXX/XXXI, s. 69-147.

Pisani V., 1959, Zu einer baltisch-estfinnischen Partizipialkonstruktion, [w:] E. Sokols i in. (red.), Rakstu krājums. Veltījums akadēmiķim profesoram Dr. Jānim Endzelīnam vina 85 dzīves un 65 darba gadu atcerei, Riga, s. 215-217.

Polák V., 1964, Les éléments finno-ougriens en slave, „Orbis” XIII, s. 568-588.

RAsK R.Ch., 1818, Undersøgelse om det gamle Nordiske eller Islandske Sprogs Oprindelse, København.

Thomason S.G., Kaufman T., 1988, Language Contact, Creolization and Genetic Linguistics, Berkeley.

Thomsen V., 189o, Beröringer mellem de finske og de baltiske (litauisk-lettiske) sprog: en sproghistorisk undersøgelse, København.

Thunmann J., 1772, Untersuchungen über die alte Geschichte einiger nordischen Völker, Berlin.

Toporov V.N., 1980, Baltijskij element k severu ot Karpat: ètnonimičeskaâ osnova ${ }^{\star}$ GALIND-kak znak baltijskoj periferii, „Slavia Orientalis” XXIX, z. 1-2, s. 247-252.

Toporov V.N., Trubačev O.N., 1962, Lingvističeskij analiz gidronimov verhnego Podneprov'â, Moskva.

Veske M.P., 1890, Slavâno-finskaâ kulturnyâ otnošeniâ po dannym" âzyka, „Izvěstîâ Obŝestva arheologii, istorìi i ètnografii pri Imperatorskom" Kazanskom" Universitetě", t. 8, z. 1, Kazan".

WATSON K.F., 1822, Über die Abstammung der lettische Sprache von der slavisch-russischen, und über den Einfluss des Gothischen unf Finnischen aufs Lettische, "Jahresverhandlungen der Kurländische Gesellschaft für Literatur und Kunst” II, s. 269-281.

Wiтczaк K.T., w druku, Zagadnienie ugrofińskiego substratu w językach bałtyckich, „Biuletyn Polskiego Towarzystwa Językoznawczego" LXXV.

Zeps V., 1962, Latvian and Finnic Linguistic Convergence, Bloomington.

ZinkevičIus Z., 1984, Lietuvių kalbos istorija, t. I, Vilnius. 


\section{Witold Mańczak's Hypothesis about the Finno-Ugric Substrate in the Baltic Languages Summary}

The paper discusses Witold Mańczak's hypothesis concerning a Finnic (particularly Balto-Finnic) substrate in the Baltic languages (Mańczak 1990: 29-38, 1993: 151, 2008: 149-152), as well as Jan Henrik Holst's critical evaluation of the problem (Holst 2015: 151-173). Mańczak lists ten arguments in support of the substrate theory:

According to Meillet (1925: 100-101), the disappearance of the neuter gender in Lithuanian and Latvian occurred under the influence of Balto-Finnic languages, since the category of gender is absent from Finno-Ugric.

Old Lithuanian displays secondary local cases (i.e. illative, allative, adessive, inessive) formed using postpositions, following the Finno-Ugric pattern (Meillet 1925: 101).

Lithuanian constructions expressing evidentiality (e.g. Lith. nešęs velnias akmenị 'a devil is said to have brought a stone') - as well as their Latvian counterparts - appeared due to substrate influence, according to Pisani (1959: 217).

Lithuanian numerals 11-19 ending in -lika (e.g. Lith. vienúolika 'eleven', dvýlika 'twelve', etc.) are of substrate origin (ibid.: 217).

Lithuanian imperative particle $-k i$ or $-k$ (e.g. OLith. dúoki 'give') reproduces a similar particle known from Finnish, according to some scholars (Toporov, Trubačev 1962: 249-250).

The alternation of voiced and voiceless consonants, as in blekai/plekai 'tripe' (Kiparsky 1968: 76-90 lists 200 such doublets in Latvian and 50 in Lithuanian), may be caused by the influence of a Finno-Ugric substrate, since the Finno-Ugric languages used to lack voiced consonants.

There are Common Baltic terms of Finno-Ugric origin, e.g. the name for 'amber': OPrus. gentars, Lith. giñtaras, Latv. dzĩtars m. 'amber' (Bednarczuk 1976: 47-48).

The use of the genitive instead of an adjective in East Baltic (e.g. Lith. lietuviu kalba 'Lithuanian language', Latv. latviešu valoda 'Latvian language'), unknown to other Indo-European languages, arose through Balto-Finnic influence - cf. Finnish suomen kieli 'Finnish language', Est. eesti keel 'Estonian language' (Bednarczuk 1968).

The territory of Latvia abounds in hydronyms of Finnic provenance, while in Lithuania we may identify the name Nemunas (the main river in the area) as well as ca. 30 other river names of potential Finno-Ugric origin (Zinkevičius 1984: 155).

The non-distinction of grammatical number in third-person finite verb forms in Lithuanian, Latvian and Old Prussian was, according to some researchers (e.g. Thomason, Kaufman 1988: 243), caused by Balto-Finnic influence.

Besides, the present author reviews Holst's critical paper on the hypothesis about Uralic substrate in Common Baltic. 